\title{
Nigerian Political Culture: The Saga of Militarism
}

\author{
Barr. Okeke V.O.S PhD \\ Department of Political Science \\ Faculty of Social Sciences \\ Anambra State University, Igbariam, \\ Anambra State, Nigeria \\ okekevos@yahoo.com \\ Dr. Ugwu Chukwuka \\ Department of Public Administration, \\ University of Nigeria, Nsukka
}

\begin{abstract}
Military rule became dominant feature of government in Nigeria only after political independence, especially from January $15^{\text {th }}$ 1966. This has become a national problem. The role of the military in the Nigerian politics has generated a lot of heated debates. The great question is, why has the military not only undertaken its traditional function of protecting the nation's territorial integrity but has vested interest in the administrative role and politics. This paper addresses questions relating to whether Nigerian political culture is a creation of militarism? Or is the militaristic political culture in Nigeria fallout from the constitution? The task of this paper is to raise critical questions on the role of the Nigerian constitution in permitting the entrance of military in governance.
\end{abstract}

Keywords: Nigeria, political culture and military

\section{Introduction}

Personal rule which has remained sub-Saharan Africa's predominant governing method since independence has often weakened military professionalism. The civil-military divide has been breached by civilians attempting to manipulate military affairs and by military officers who pursue political control of the state. The resultant weaker militaries increasingly threaten state legitimacy in the post-Cold War era. Prolonged military rule in Africa has created severely weakened nations, fractured along religious and cultural lines. It has impoverished and economically stagnated vast segments of the civil society. Though Nigeria has since 2009 witnessed uninterrupted democracy till this 2012, Momoh and Thovoethin (2001) has noted that, out of approximately forty-one years of Nigeria's independence, civilians have successfully ruled the country for only twelve years, while the military have ruled the country for about twenty-nine years. While Nigeria has had seven military regimes, it has had just four civilian regimes (Shonekan's Interim government and Obasanjo's civilian rule inclusive). This situation has enormous impact on the political development of Nigeria. Furthermore, Prof. Olayiwola Abegunrin cited by Abidde (2012) recently accused the military of destroying Nigeria's institutions by some of the policies they promulgated and pursued, beginning in the General Yakubu Gowon era. He posited that some of the policies they pursued, along with all the coups and countercoups, helped weaken, and in some cases, destroyed the sense of nation-building and sense of self in Nigeria. A great many of Nigeria's national treasure were prosecuted, persecuted, harassed, jailed, or sent into exile; and in some cases, the military simply made life and living 
miserable and unbearable, Abegurin continued. Though the military in Nigeria have been disengaged from power, the effects of their past years of ruling the country have not left the country. The present democratic governance has failed to reflect the true features of democracy as human rights abuse has continued to abound in the country and the constitution is not yet the supreme law in the land, rather the whims and caprices of the leaders have remained supreme. Even the constitution itself still contains attributes of the military culture.

Thus, this research work raises the following questions: what are the reasons why every military regime was much concerned in writing a new constitution for the nation? What then are their reasons for taking over political leadership as against that of the military? Is Nigerian problem a constitutional matter? If it is, can the problem be solved by the constitution written by the military? If it is, how? If it cannot, how can it be possible for the civilians to write a good constitution for themselves that will usher in good governance and prevent the military from the nation's politic? The above questions will help to shape the rest of this work thus the thrust of this paper is to examine the Nigerian political culture: the saga of militarism.

\section{Theoretical Framework}

Institutional arguments rely not on aggregations of individual action, or on patterned interaction games between individuals, but on "institutions that structure action" (Clemens and Cook, 1999). Institutions are emergent, "higher-order" factors above the individual level, constraining or constituting the interests and political participation of actors "without requiring repeated collective mobilization or authoritative intervention to achieve these regularities" (Jepperson, 1991). Institutional theories as applied to politics posit two distinct forms of institutions' influence over policy and political action. Institutions can be constraining, superimposing conditions of possibility for mobilization, access, and influence. Institutions limit some forms of action and facilitate others. Arguments about institutional constraint evoke an "architectural or maze-like" imagery; to the extent that institutions are hypothesized to proceed from powerful states, such architecture becomes a "concrete, massive, autonomous" fortress (Clemens and Cook 1999). Theories of "political mediation" (Amenta et al. 2005) and "political opportunity" (Meyer and Minkoff 2004) are, partially, institutional constraint arguments, to the extent that they posit that political institutions limit the conditions under which organized interests mobilize and attain collective goods from the state. The main thrust of our theoretical framework here is that macro-level political institutions shape politics and political actors, who act under constraints that may influence their impact on states and policies, refashioning political institutions in the process, and so on. More so, institutions are patterns of behavior that affect the behavior of individuals. Normative institutionalism sees institutions as defined by the rules reflected in the behavior of individuals belonging to the institution. Rules describe a certain code of conduct (logic of appropriateness) that provides the individual with a civic identity, which constrains and forms his actions. Social actions are informed by this 'logic of appropriateness' rather than the objectives aimed for by the institution or the individuals (logic of consequence). Hence, an institution is both norms and actions that reinforce each other in a dialectical and selfreinforcing relationship. The relevance of the institutional theory in studying the military and their activities and contributions to the militaristic nature of the Nigerian polity is found in the conceptualization of the military, first as an institution within the state structure saddled with the 
responsibility of maintaining the internal and external security of the Nigerian state. Being an institution with high degree of internal discipline and hierarchy which commands high sense of respect and obedience among its members, the military institution has a high degree of influence on the manner of both thought and action of its members.

Again, being an institution known to be found on the principle of force, militarism, command and total respect, the institution has also instilled in its members these principles and this has been an important determining factor of the actions and inactions of the past leaders of Nigeria who have military backgrounds. Thus, since Nigeria has been governed by the military for many years more than it was governed by civilians without any military background, the society in Nigeria has become militarised as the military institution has continued to play major role in shaping the actions and inactions of its members both in and out of government.

\section{Conceptualization of terms}

\section{Culture}

Going by the positions of authorities like Edward B. Taylor, culture as a concept is a complex whole, which includes knowledge, beliefs, skills, arts, morals, laws, customs and any other capabilities and habits acquired by man as a member of the society. It simply means the ways of life of the people and/or the ways people do their own things. These ways reflect in the people's life styles and are interconnected in the proper functioning of every socio-institutional structure in which politics in done. Politics is the act of governance. It has its own culture or methodology. This differs from society to society.

Culture in totality speaks of people in a given society. It is a reflection of an existing behavioural pattern that is unique to a people and varies from one society to another. This means that others may not appreciate what others appreciate as their guiding principles. The variations of these behavioural patterns are determined by the existing values, beliefs, philosophies, principles and norms of the people. Hence, we need to admit that every individual is a product of his/her culture. It defines our attitudes, values and every aspect of our lives.

Culture exerts pressure on us subject to the limit imposed by inheritance and socio-political conditions. The elements that are found in culture determine our personalities and levels of our political interest. It is interesting to note here that every individual is expected to conform to the provisions of his/her culture. Conformity at this level is rewarded while non-conformity is punished.

\section{Political Culture}

At this level of our discussion, we may begin to ask ourselves what is political culture. The definition of political culture is not radically different from what we regard as culture. Dare et al (1987) argues that political culture is the product of history of both the political system and the individual members of the society. They believe that the experiences of both the individual and the community interact to produce an aggregate pattern, which is regarded as culture. Political 
culture therefore is an aspect of the large culture. It is an overall distribution of citizen's orientations to political objects that have to do with government, the regime and the political community. The position of Nwankwo (1990) is similar to that of Dare et- al. He sees political culture as made up of attitudes, beliefs, emotions and values of society that relate to the political system and to political issues. It is therefore potent to agree that the political culture of a nation consist of the ideas, traditions, assumptions and accepted rules of the game that make up the framework within which the political system functions. The political culture of a nation deals with the network of processes, methods, patterns and problems associated with governance. This means that Nigeria as a nation has her own political culture, which is radically unique to the people and varies from that of other nations whether in the continent of Africa or in another.

\section{Nigeria's Political Culture}

The impact of almost 30 years of a military regime can be seen at all levels of Nigeria's political and daily life. Nigerians aptly describe its impact as the "militarization of the Nigerian psyche". The violence and insecurity, which is widespread in the country, is to a large extent the result of the development of a military culture. Physical confrontation, the preserve of the military and police forces, is extensively resorted to by citizens as a consequence of the structural violence brought about by the military. Demilitarizing Nigerian social life is therefore a prerequisite for the democratic development of the country. The long direct participation of the military in Nigerian politics has received a lot of scholarly works. This has also led to the theorizing on the reasons for military rule in Nigeria.

(i) The first category of scholars opine, that the problem of military intervention in politics is rooted in some factors internal to the organizational structure of the military institution. Proponents stress that certain characteristic of the military like their sense of nationalism, cohesion, Puritanism and austerity, professionalism etc impel them to move into the political arena to rescue the state from wreckage (Huntington, 1957; Janowitz, 1964).

(ii) The second category of scholars attribute military intervention to societal factors which are essential to the military institution. They stress societal and structural weakness, institutional fragility and low levels of political culture etc, which act to propel the military to occupy the political vacuum (Luckham, 1971; Welch Jnr, 1969; Huntington, 1968).

(iii) The third view while focusing specifically on Africa gives an Afrocentric perspective of the problem. Proponents question the apolitical nature of the military and unnaturality of Military intervention in politics. They stress the fact that the military is part and parcel of the process of state formation and is therefore a political institution. Further, that the idea of an apolitical professional military is alien to Africa because in traditional African states the distinction between the spheres of economy, polity, religion and social were blurred. Thus, the concept of civilian supremacy is a borrowed term in its application to Africa (Elaigwu, 1979; Mazrui, 1975).

\section{Civil-Military Relations}


The military's attitude toward civil rights and liberties amply illustrates how it perceives the civil society. Military regimes have a distorted notion of civil society - a society based on expediency and governed not by law but according to the whims of the military hierarchy.

Every aspect of the civil society remains subject to the unchecked and unreviewable authority of the military. There are no standards against which the legality of military governmental actions can be judged and no clearly defined and objectively verifiable rules governing conduct. Opposition and diverse opinions are muzzled, favoritism replaces meritocracy, and the public good is subordinated to the selfish interests of the ruling military junta. In dealing with the civil society, the desire to ensure total domination preoccupies the military. Consequently, the military regime confers on itself a broad array of powers under which it can abridge rights and ensure compliance with its policies. The regime progressively obligates the institutions, rules, and processes that protect the citizens against abuse, thus leaving the citizens at the mercy of the despotic rule.

\section{The Nigerian Military in Politics}

The statutory responsibility of the military is to protect the territorial integrity of the nation against external attack. It is an agency that is absolutely committed to the management of violence and prosecution of war against external invasion and attacks. It is a professional body. Its responsibilities are uniquely structured and cannot be performed by another body except itself. Member's roles and responsibilities are stereotyped. They are structured and defined. The identities of members are glaring too. In advanced nations like the United States of America (USA), Great Britain, Japan and many others, the military sticks to their roles. This is not the same in the Third World Nations like Nigeria. The problem is foundational. From historical perspective, the foundation of Nigeria's political life is layed by military leaders under colonial and neo-colonial rules. Cecil Rhodes, the Lugard, Richardson, Clifford's, Bourdilon, Littleton's, McPherson all were retired colonels and Generals of the British War Machine. They were all compensated with postings to the British Colony now Nigeria as Governor Generals, LT governors or Residents. Their styles of governance were military oriented. They did things with command, and they implemented policies and programmes with dispatch without minding their implications on the public. The emergence of a new colonial Governor General and the writing of a new colonial constitution were as a result of unsatisfactory policies and their methods of implementations. This led the colonized people to quest for their freedom. Between 1960 and the year 2007, the military in uniform, have ruled Nigeria for twenty-nine good years (29 years). The military out of uniform have ruled the nation for eight years and the civilians were only permitted to rule for only ten years. By implications, the military in and out of uniform have ruled Nigeria for thirty -seven years. From all indications, Nigeria will celebrate her fortyseventh birthday on October first, 2007. By calculation wise the military in and out of uniform have occupied seventy- nine percent $(79 \%)$ of the nation's leadership since independence while the civilians only occupied twenty one percent $(21 \%)$ i.e. $37 / 47$ as against $10 / 47$. This situation demands for a concern. It needs to be addressed from its roots to determine a way out.

Table one (1): Civilian / Military Out of Uniform Regimes

\begin{tabular}{|l|l|l|l|}
\hline S/No & Date of Commencement & Head of State/ & Duration of Regime \\
\hline
\end{tabular}




\begin{tabular}{|c|c|c|c|}
\hline & & President & \\
\hline 1 & $1^{\mathrm{ST}}$ Oct, 1960 & $\begin{array}{l}\text { Dr. Nnamidi Azikiwe } \\
\& \text { Alhaji Tafawa } \\
\text { Balewa (civilians) }\end{array}$ & $\begin{array}{l}1^{\text {st }} \text { Oct, } 1960-14^{\text {th }} \text { Jan. } \\
1966\end{array}$ \\
\hline 2. & $1^{\mathrm{ST}}$ Oct, 1979 & $\begin{array}{l}\text { Alhaji Shahu Shagari } \\
\text { (civilian) }\end{array}$ & $\begin{array}{l}1^{\text {st }} \text { Oct, } 1979-31^{\text {ST }} \\
\text { Dec. } 1983\end{array}$ \\
\hline 3. & August $26^{\mathrm{TH}} 1993$ & $\begin{array}{l}\text { Chief Ernest Shenekon } \\
\text { (civilian) }\end{array}$ & $\begin{array}{l}26^{\text {TH }} \text { Aug. } 1993-17^{\text {th }} \\
\text { Nov. } 1993\end{array}$ \\
\hline 4. & May $29^{\text {th }} 1999$ & $\begin{array}{l}\text { Rt. Gen. Olusegun } \\
\text { Obasanjo (military out } \\
\text { of uniform) }\end{array}$ & $\begin{array}{l}\text { May } 29^{\text {th }} 1999 \text { May } \\
29^{\text {th }} 2007\end{array}$ \\
\hline 5. & May $29^{\text {th }} 2007$ & $\begin{array}{l}\text { Alhaji Umaru Musa } \\
\text { Yar'adua (civilian) }\end{array}$ & $\begin{array}{l}\text { May } 29^{\text {th }} 2007-\text { May } \\
29^{\text {th }} 2011\end{array}$ \\
\hline
\end{tabular}

Table two (2): The Military Regimes

\begin{tabular}{|c|c|c|c|}
\hline S/NO & Date of Coup & The Head of State & Duration of Regime \\
\hline 1. & Jan. $15^{\text {th }} 1966$ & Major Gen. J.T.U. Aguiyi Ironsi & $\begin{array}{l}\text { Jan. } 15^{\text {th }}-\text { July } 29^{\text {th }} \\
1966\end{array}$ \\
\hline 2. & July $29^{\text {th }} 1966$ & Gen. Yakubu Gowon & $\begin{array}{ll}\text { July } 29^{\text {th }} & \text { 1966-July } \\
29^{\text {th }} & 1975\end{array}$ \\
\hline 3. & July $29^{\text {th }} 1975$ & Gen. Murtala Mohammed & $\begin{array}{lll}\text { July } & 29^{\text {th }} & 1975-F E B \\
13^{\text {TH }} & 1976\end{array}$ \\
\hline 4. & $14^{\mathrm{TH}}$ Feb. 1976 & Gen. Olusegun Obasanjo & $\begin{array}{l}14^{\text {th }} \quad \text { Feb. } \quad 1976-1^{\text {st }} \\
\text { Oct. } 1979\end{array}$ \\
\hline 5. & Dec. $31^{\text {st }} 1983$ & Major Gen. M. Buhari & $\begin{array}{l}\text { Dec. } 31^{\text {st }} 1983- \\
\text { Aug27th } 1995\end{array}$ \\
\hline 6. & Aug. $27^{\text {th }} 1985$ & Gen. Ibrahim B. Babaigida & $\begin{array}{l}\text { Aug. } 27^{\text {th }} 1985-\text { Aug } \\
25^{\text {th }} 1993 .\end{array}$ \\
\hline 7. & Nov. $17^{\text {th }} 1993$ & Gen. Sani Abacha & $\begin{array}{l}\text { Nov. } 17^{\text {th }} \text { 1993-June } \\
9^{\text {th }} 1998\end{array}$ \\
\hline 8. & June $9^{\text {th }}$ & Gen. Abdusalami Abubakae & $\begin{array}{l}\text { June } 9^{\text {th }} 1998-\text { May } \\
29^{\text {th }} 1999 .\end{array}$ \\
\hline
\end{tabular}

Like we had discussed before in this paper concerning the military writing and presenting constitutions which are working documents for all persons, it is important to note that the act of constitutional writings and reforms since independence till date were done by the military. This is necessary since the constitution defines and/or protects the vested interest of the military in governance. From historical point of departure, all the constitutions that have been in force from the time of independence till 2007 were all written by the military in and out of uniform. For instance, in 1979, General Olusegun Obasanjo wrote a constitution, which ushered in Shehu Shagari's civilian regime on October first 1979. In 1989, General Ibrahim Babangida organized a constitutional conference, which resulted in the release of a new constitution for the nation. The constitution provides mechanisms and processes through which the third republic could be 
established. The hallmark of its provisions was the empowerment of the military government of Ibrahim Babangida to establish two party structures i.e. Social Democratic Party (SDP) and National Republican Convention (NRC). By this empowerment, the masses were not given the opportunity to form their own political parties rather parties were formed and imposed on them. Their choices were limited between two options whether they liked it or not. In other to realize this, government constructed two party structures or secretariats in each of the local governments nationwide. They also built state headquarters for each of the two political parties. The plan of government was to hide under one of the political parties to consolidate its stand as a civilian government / regime. The government could be military out of uniform. The cry of the yearning masses for a democratic government led to the collapse of that government. In August 1993 an interim government was established. The government was intended among other things to prepare a solid ground for a smooth transition to civilian rule. Chief Ernest Shenekon was made an interim head of state by General Ibrahim Babangida. It was not surprising that Shenekon's government did not last. It did not gather momentum on governance to fulfill its mandate when on November, $17^{\text {th }} 1993$ General Sani Abacha in their usual style took over government through a military coup. General Sani Abacha felt that the 1989 constitution was not in his favour. He saw reasons why a new constitution should be written. On this premise, he wrote another constitution in 1995. It came to usher in the fourth republic. Remember, that the third republican constitutional interest was not realized. Now it's for the fourth republic. When General Sani Abacha died, on June $8^{\text {th }} 1998$, everything about his constitution was abandoned. General Abdulsalam Abubarka who took over from him began on a fresh note a new constitution. His constitution was finally written and signed into law in 1999. The 1999 constitution later ushered in the fourth republic in which a retired military head of state, Rtd. General Olusegun Obasanjo was declared elected president of the Federal Republic of Nigeria. It is not a hidden secret to admit that each of these constitutions protects the interest of the writers more than that of the governed. The military elite' classes were more comfortable and protected by these constitutions. The writers of these constitutions benefit from it when they succeed in bringing to office as president their military colleagues whether retired or tired in military service. It is also beneficial to them when their co-horts are placed at varied positions of authorities to determine the faith of the citizens. The provisions of these constitutions do not spell out punishments for their activities, which go contrary to democratic process and the norms of the society. The constitutions became coverage for their unapproved actions. A situation where a coup is plotted, the constitution is automatically suspended. They depend on edicts for their administrative assignments and actions. When they feel the people's pressure on them to hand over to a civilian rule is high, they decide to write a new constitution in which its provisions will do them no evil.

As usual and in their normal military style, Rtd, General Olusegun Obasanjo opted for a constitutional review in the year 2005. The review was meant to protect his interest for his third tenure civilian agenda. This unhidden agenda of continuity met its doom when the national assembly (both federal house of representative and senate) could not approve of it. Campaigns were taken to all the states to rally support. Most of the states where the governing elites had longed for the same continuity, the governing elites voices were heard echoing in agreement as against the views of their governed majority. 
This culminated to national crisis. The pressure from the public was so much that the power of the governed majority outweighed that of the ruling class. In this process, the idea was submerged. It was allowed to die in silence. It naturally crippled, hence the general elections of 2007.

\section{Nigeria's Militaristic Political Culture: the Saga of Militarism in Nigeria}

In this section of the work, we shall argue that the militaristic nature of the Nigeria's political culture is both an outcome of the constitutional provisions and the long participation o the military in the governance of Nigeria. Howe (2001) writing on the unprofessional nature of African military from post-independence posits that, the "unprofessional" argument assumes that national political structures and values help determine a force's character and that Africa's prevailing system of personal, rather than institutional, rule has proven incompatible with military professionalism. Armed forces that are neither militarily competent nor politically responsible threaten national development. Military professionalism is a two-way street. Civilian and military officials agree not to cross the divide into each others' affairs. The armed forces enjoy considerable jurisdiction in military matters: they determine selection and promotion of personnel using their own merit criteria, and they implement policies of command and control, manpower, firepower, intelligence, communications, and logistics. The balancing of power among government agencies and between the government and the public specifically helps to check unpopular military incursions into foreign lands. Thus, the full involvement of the military in the overall governance of Nigeria is in itself an aberration both against the professional principle of the military institution itself and against the constitution of the Federal Republic of Nigeria prior to the 1966 coup and other subsequent years. Although the trend of the involvement of retired soldiers in politics became noticeable under the Babangida political transition program (1986 - 1993), it seemed to have reached an unprecedented and worrisome dimension, under the Abubakar political transition program (1998 - 1999). It is estimated that no less than 130 rich and influential retired military officers are members of the Peoples Democratic Party (PDP), the current ruling party in Nigeria at the Federal level. Amongst them, at least 30 are of the rank of Major General and above, while the others comprise mostly of colonels and other ranks. Indeed, some have aptly dubbed the PDP as a party of "Army arrangement" (Nmodu, 1999). Currently, this social category constitutes the most powerful force in the political arena in Nigeria. Indeed, the pre-eminence of the "retired soldier" in Nigerian politics is best attested to by the fact that Nigeria's former president, Olusegun Obasanjo is a retired military general. Even the current Senate President, David Mark is also a retired military man.

A military regime is a socio-political aberration built on the Austinian theory of legal positivism-by force rather than the consent of the governed. Military regimes are essentially dictatorial and by their modus operandi incompatible with constitutional democracy. Two dominant factors shape military administrations in Africa: (1) the need to dominate the civil society, and (2) the desire to secure its power base. These factors engender a strong dictatorial mind set. In governing the nation, the military is omnipresent, unchecked by any constitutional restraints. Military regimes have a disturbing contempt for law and legal rules; they care only 
about achieving their stated objectives. Military regimes, which perceive themselves as above the laws that govern society, have systematically erased society's lines of authority that promote accountability and respect for citizens' rights.This corresponds to the Marxist notion of law as instrument of domination and oppression. Laws promulgated by the federal government are called decrees. Under a military regime, decrees are enacted by the highest legislative organ of the military administration. The highest legislative body in Nigeria has been called various names by each military administration. The Gowon administration (1966-1975) and the Buhari regime (1983-1985) called it the Supreme Military Council, the Bagangida regime (1985-1992) called it the Armed Forces Ruling Council, and the Abacha administration (1993-1998) called it the Provisional Ruling Council. Laws enacted by state governments are called edicts. To further bolster its domination of civil society and to achieve stated objectives, military regimes typically exhibit contempt for constitutional democratic order. The Constitution (Suspension and Modification) Decree, which is the first law that virtually all military regimes in Nigeria promulgate, illustrates the military's contempt for the rule of law. This decree confers plenary power on the military to ignore or dismantle existing legal and political institutions. Parts of the constitution are suspended, abrogated, or modified; political parties are disbanded and civil liberties are severely circumscribed. This decree usually heralds the military's desire to neutralize legal rules and processes that constrain the exercise of state power.

How then is the constitution of Nigeria and the military institution responsible for the militaristic nature of Nigeria's political culture? We have already stated above in this work the nature and principle of the military institution which is built on autocratic leadership and force. The military regimes in Nigeria did not hide this feature in all the years they piloted the affairs of this country. This starts from the manner in which they took over power starting from 1996 coup - through a forceful means. They made laws by decrees and edicts which were neither debatable nor revocable except by them. An example of this could be seen in the proclamation of the creation of many states which exist today by the Babangida Regime and other regimes. The several harassments and humiliation of Nigerians, abuse of human rights and subsequent killings witnessed in those military regimes are all. The civil society organizations and interest groups were clamped down upon and the Nigerian political environment was too hot for them to operate. The press found it very difficult to freely report certain events and activities of the government. Those who tried to do their work well did so at the risk of their freedom and their lives as many journalists were jailed and some others murdered. Ethnic agitations as well as struggle for regional and group rights were seen as treason by the military regimes. The hanging of Ken Sarowiwa and the Ogoni six are still in the memories of Nigerians. These examples and many other instances instilled fear in the Nigerians and made people lose the sense of accountability and contribution to the governance of the country. The prolonged period of military governance made this to become a culture for Nigeria even in the present democratic government system.

Again, even the present democratic era, the military has still not really disappeared from participating in governance. President Olusegun Obasanjo who became a civilian president is a retired Army General and his governance system also reflected his military background as he never made proper consultations nor followed due process in most of the activities carried out by his government. In the present period, the National Assembly and State Assemblies are filled 
with retired military personnel, a typical example being the president of the Senate, Senator David Mark. Many government agencies and parastatals, committees etc are also headed by these retired and serving military personnel. This situation has continued to reflect the militaristic aura in the policies, actions and inactions of the government even in the contemporary democratic setting. Thus, the military and the military institution are responsible for the militaristic nature of Nigeria's political culture.

Looking at the contribution of Nigeria's constitution to the militaristic nature of the country's political culture, it already known that the military will always produce a military (forceful) fruit and this is reflected in the Nigerian constitutions made by the military. It has been argued in many quarters by Nigerians that the current 1999 constitution which was derived from the 1979 constitution is an apparent lie against Nigeria's citizens as the introductory part of the constitution current constitution states 'we' while the citizens of the country were not part of the constitution making process. Rather, the constitution was a product of a few persons selected by the military. In order words, it reflects the whims and caprices of the military. The militaristic nature of Nigeria's political culture as a result of the constitution is also found in many decrees which are just renamed while the contents remained. A typical reflection of militarism in the laws of Nigeria is the Land Use Act. The body of law is the handwork of the military known as the Land Use Decree of 1978 which has continued to receive several amendments civilian administrations with minimal changes. This law grants the government the sole owner of all lands in Nigeria. Thus, the government has right to occupy lands anywhere it finds one. Nigerians have continued to suffer in the hands of the government and its agencies as people's lands are taken away from them with force thereby reflecting the militaristic political culture. Centralization of power as encouraged by the constitution is the highest point of the position of this work. IDEA (2000) posits that the deficiencies of Nigeria's constitution deficiencies include: unequal separation of powers, inadequate devolution of power and ambiguous definition of roles and duties of states and local councils, concentration of resources on the federal government, conflict on social and religious rights, not addressing the role of traditional leaders and the redefinition of citizenship. The centralization of power at the centre which is an outstanding feature of military regimes has continued to be practiced even in the contemporary democratic administrations. This has also been the bane of Nigeria's federalism. A comparison of the exclusive, concurrent and exclusive lists of the constitution shows that the federal government has greater role to play including the extraction of mineral deposits and distribution of finance thereby making the centre the pivot of all political cum economic activities. Going through all the present 1999 constitution shows this in clear terms.

\section{Conclusion}

By the nature of military tradition, it is not an unhidden fact that the military in the politics of nations is out of place. It is unconstitutional, abnormal and a slap on the nations socio-political and cultural integrity. This is one of the basic reasons why there is always a cry against military regimes the world over. In an event of a military takeover of government, the citizens are always gripped with fear. There is always fear of intimidation, suppression, pressures and commands. The citizens only face actions from the commandant who is usually regarded as the head of state. Everything is done with military precision and dispatch. The power of the constitution is watered 
with edicts. Therefore, the citizens lack constitutional protections; hence there is always a threat to their fundamental human rights and responsibilities. It is therefore right to conclude that the major problem, which hinders the socio-political stability of the nation is the foundation laid on a wrong political culture. The political culture is military oriented. The military becomes the determining force on the issues surrounding the Nigerian political life. It is not in doubt that there are some positive contributions of the military in the governance of the Nigerian people. For instance, they are solely responsible for the division of the nation into States and Local Government structures, which has given the people sense of belonging, they established and maintained universal basic education programme, National Youth Service Corps, opened up Federal Schools at all levels established National Directorate of Employment (N.D.E.), Structural Adjustment Programme and a host of others. However, Nigeria, having enjoyed interrupted democratic governance since 2009, is expected to have done away with traits of militarism since military system of governance works opposite democracy. The present militaristic political culture is expected to have been changed to real democratic practices and this is what the citizens expect.

\section{Recommendations}

The era of the military taking over the power of the state through coup d'etat has been a past issue but the effects of their rule are still being felt in the Nigerian polity. This is reflected in the militarized political culture in the country. What possible panacea is available in correcting this bizarre situation? The needed panacea to the problem of military in governance is not farfetched. The answers are hereunder presented. We need to first understand that the constitution of a country is the hallmark of her national culture. It is also a prelude to the nation's development; politically and otherwise. A good constitutional repositioning of methods of governance will help in the rebuilding of a sound political culture. It has been discovered that Nigerian political problem is a constitutional matter. This is one of the major reasons why any military in power will always stick to their culture of writing a new constitution that will protect their interest. The civilians should therefore, write a constitution for themselves and/or reform the already existing constitution. Furthermore, in writing the new constitution or amending the existing one, certain provisions should be made that will frustrate the entrance of the military in the nation's politics. For instance, the constitution should provide that;

1. Both attempted and successful coups should be regarded as a treasonable crime, which is punishable by death. Therefore, offenders should be punished accordingly.

2. The implementation of one (1) above shall be the statutory responsibility of a successive civilian government. This is to say, that no matter how many years it takes a new civilian government to emerge in the face of military intervention, all those who masterminded the coups should be brought to book. It means that ex-heads of states are subject to legal prosecution. This will serve as a deterrent to others who may have the intent to commit treasonable crime.

3. Military personnel always demonstrate their cultural skills whether retired or not. On this basis, Col Madaki Y. in Odey (2003) laments on the activities of his colleague Rtd Gen. Obasanjo. He laments, I am worried because things have not gone the way we thought they would if the military vacated. The military have been replaced by another set of people; lions and tigers in sheep's skin. That is the unfortunate thing. In view of this, no 
military personnel whether retired or not should be allowed to contest for any political office. He or she can be given political appointment but should not contest for any contestable position both at local, state and federal government levels.

4. The military should be properly paid and cared for. They should be paid highly due to the risks involved in their job. Just like health personnel are paid high wages in many societies of the world because of high value to life which they swore to protect and preserve, so should recognition be given to the roles of the military in the security of the nation. Like the pilots and medical doctors' jobs are risk intensive, so is the military. Theirs is more risky than others since they pledge their life in loyalty to the nation. To them, if they die, they die; if they are consumed let them be consumed provided the security of the nation is ensured. There should be high value placement on their roles.

5. There should be a compulsory annual in-service training for every military personnel. This training will be geared towards educating and socializing them on their expected roles and responsibilities. They need to be reminded of their duties as often as possible.

6. Promotions of the military personnel should be treated with dispatch. This will encourage them to be more dedicated in serving the nation.

7. Military pensions and gratuities should be paid and on time too. This will help those who are retired to settle down properly and live at least on the average.

8. External bodies should be controlled in their exercise of influence on the activities of the military. What we mean here is that there should be a serious check on how the military of other nations interact with that of Nigeria. This is because researches reveal that external bodies are responsible for the sponsorship of military coups in many parts of the world especially in the Third World Nations. Some governments in other nation-states are contributory to the sponsorship of coups d etats world over. Their reason might be on selfish grounds.

9 In order to sustain a true democratic process, the constitution should frown at corrupt practices at all levels. People should be made to pay for the crimes they commit not minding their socio-political status.

10 Also the constitution should only empower one term government. That is to say that nobody should be allowed to occupy a politically elected position for more than four (4) years. All elections at all tiers should be done in one day. The tenures of politically elected officers should be the same. (4 years) at all level and tiers.

\section{Reference}

Adejumobi, S. and Abubakar M. (1999), The Political Economy of Nigeria Under Military Rule: 1984-1993. In Adejumobi and Abubakar (eds.), The Nigerian Military and The Crisis of Democratic Transition: A Study in The Monopoly of Power. Lagos: Civil Liberties Organization.

Amenta, Edwin, Neal Caren, and Sheera Joy Olasky. 2005. "Age for Leisure? Political Mediation and the Impact of the Pension Movement on U.S. Old-Age Policy." American Sociological Review 70:516-538. 
Clemens, E. S. and Cook, J. M. (1999), "Politics and Institutionalism: Explaining Durability and Change." Annual Review of Sociology 25:441-466.

Dahrendorf, R. (1959) Class and class conflict in industries society London: Rutledge and Kegan Paul

Dare, L. et -at (1987). A textbook of government for Senior Secondary School, Ibadan: Onibonoje Press \& Book Industries Ltd.

Diamond, L., Anthony, K-G. and Oyeleye O. (1997), (Eds.) Transition Without End. Ibadan: Vantage Publishers.

Dunkerley, David (1976). Introduction to psychology, U.S.A. : Mc-Graw-Hill Inc.

Elaigwu, J. I. (1979), "Military Intervention in Politics: An Africa Perspective”. Paper Presented at the International Studies Association Conference, Toronto, Canada, $24^{\text {th }}-29^{\text {th }}$ March

Federal Republic of Nigeria (1978), The Land Use Decree

Federal Republic of Nigeria (1999), The Constitution

Howe, H. M. (2001), Ambiguous Order: Military Forces in African States. Boulder: Lynne Rienner Publishers.

Huntington, S. P. (1968), Political Order in Changing Societies. New Haven: Yale University Press.

IDEA (2000), International Idea's Programme in Nigeria. http://www.idea.int/publications/country/upload/nigeria 07.pdf

Janowitz, M. (1964), The Military in the Politics of New Nations. Chicago: University of Chicago Press.

Jepperson, R. L. (1991), “Institutions, Institutional Effects, and Institutionalism.” Pp. 143-163; in The New Institutionalism in Organizational Analysis (ed.) by W. W. Powell and P. J. DiMaggio. Chicago, IL: University of Chicago Press.

Luckham, R. (1971), The Nigerian Military: A Sociological Analysis of Authority and Revolt 1960-67. Cambridge: Cambridge University Press.

Lugard, Lord (1922). The dual mandate in British tropical Africa. London : Frank Class \& Co. Ltd. 
Meyer, David S. and Debra C. Minkoff. 2004. "Conceptualizing Political Opportunity." Social Forces 82:1457-1492.

Momoh, A. and Thovoethin, P. (2001), An overview of the 1998-1999 Democratization Process in Nigeria. http://unpan1.un.org/intradoc/groups/public/documents/CAFRAD/UNPAN009286.pdf

Nwankwo, B.C. (1990). Authority in government. Benue : Aimund Publishers.

Nweke, Joshua O. (2004) Citizens and Nigerian political life, the saga of militarism, a revolutionary approach. Enugu : Cheston Agency Ltd.

Nmodu, D. (1999), PDP's Army Arrangement. Tell, January 11, p. 27.

Nwabueze, B. (1984), The Process and Challenge of Legislation in a Military Government. 17 Nig. B.J. 73

Odey, J.O. (2003). This madness called election 2003. Enugu: SNAAP Press Ltd.

Peters, B. G. (2000), Institutional Theory: Problems and Prospects. The Political Science Series.

Welch JNR, C. (1970), Soldier and the States in Africa: A Comparative Analysis of Military Intervention and Political Change. Evanston: Northwest University Press. 